
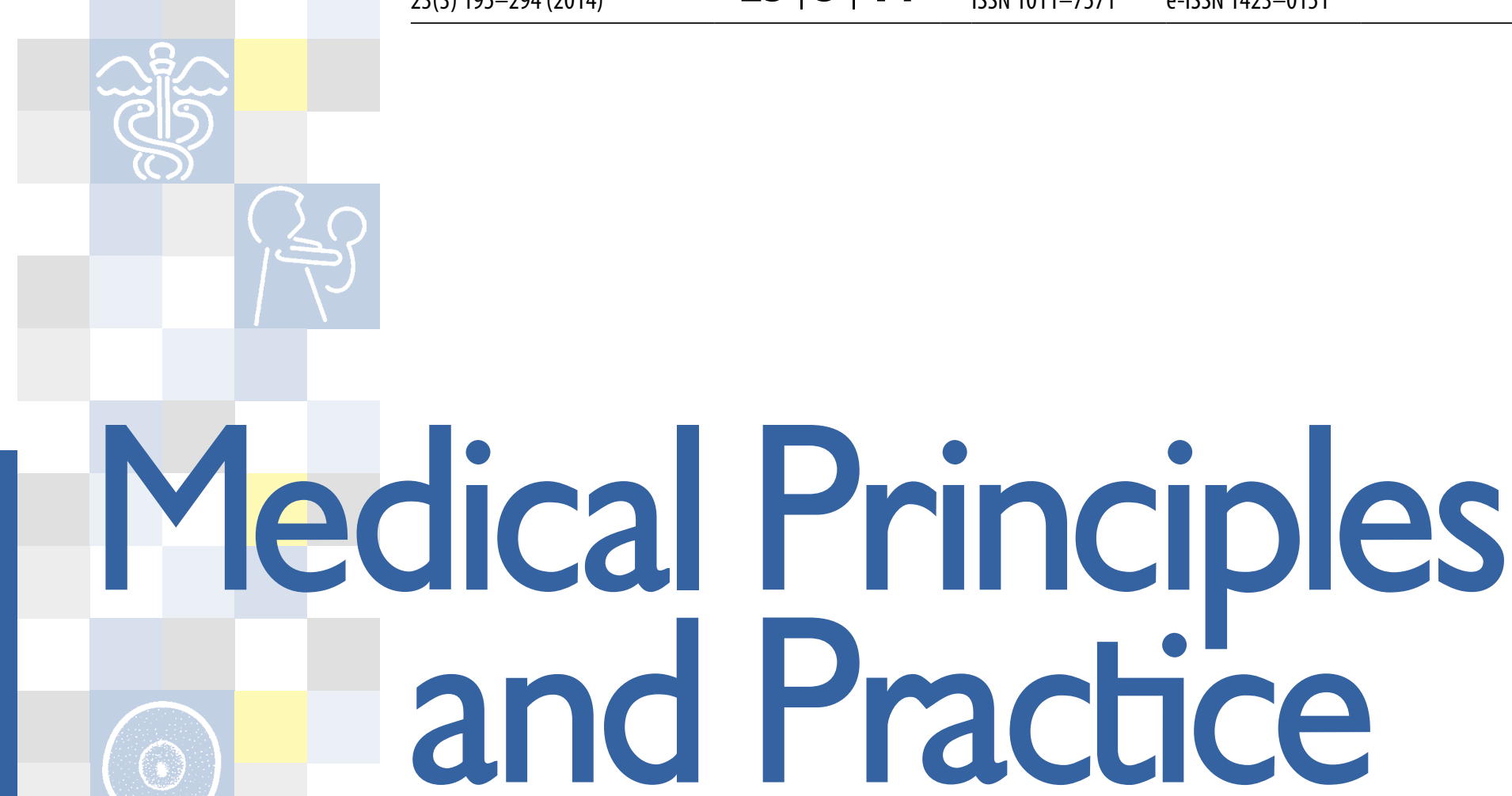

\title{
International Journal of the
} Kuwait University Health Sciences Centre

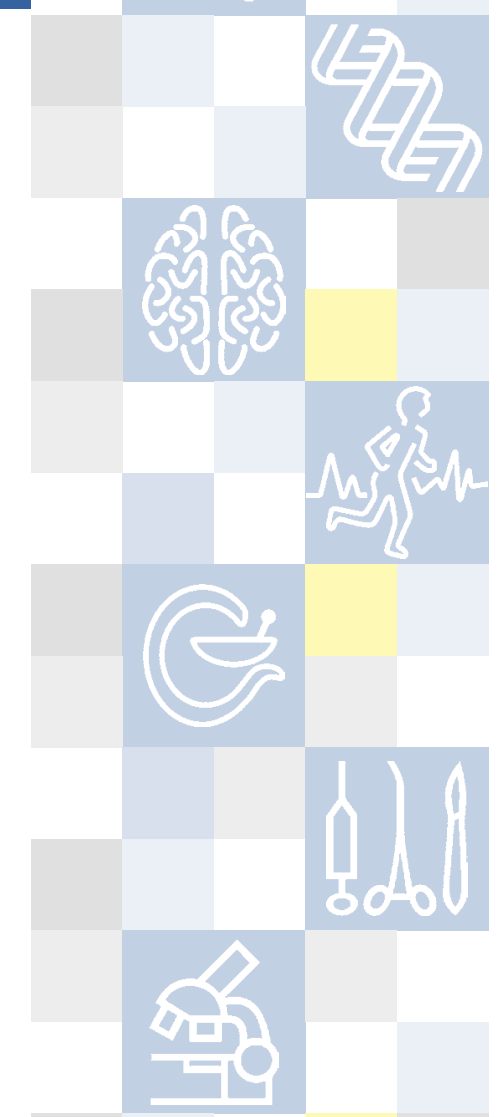

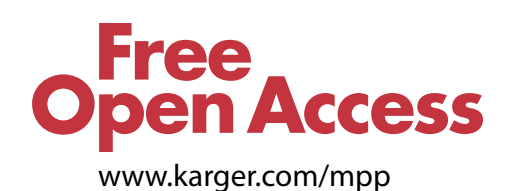

www.karger.com/mpp 


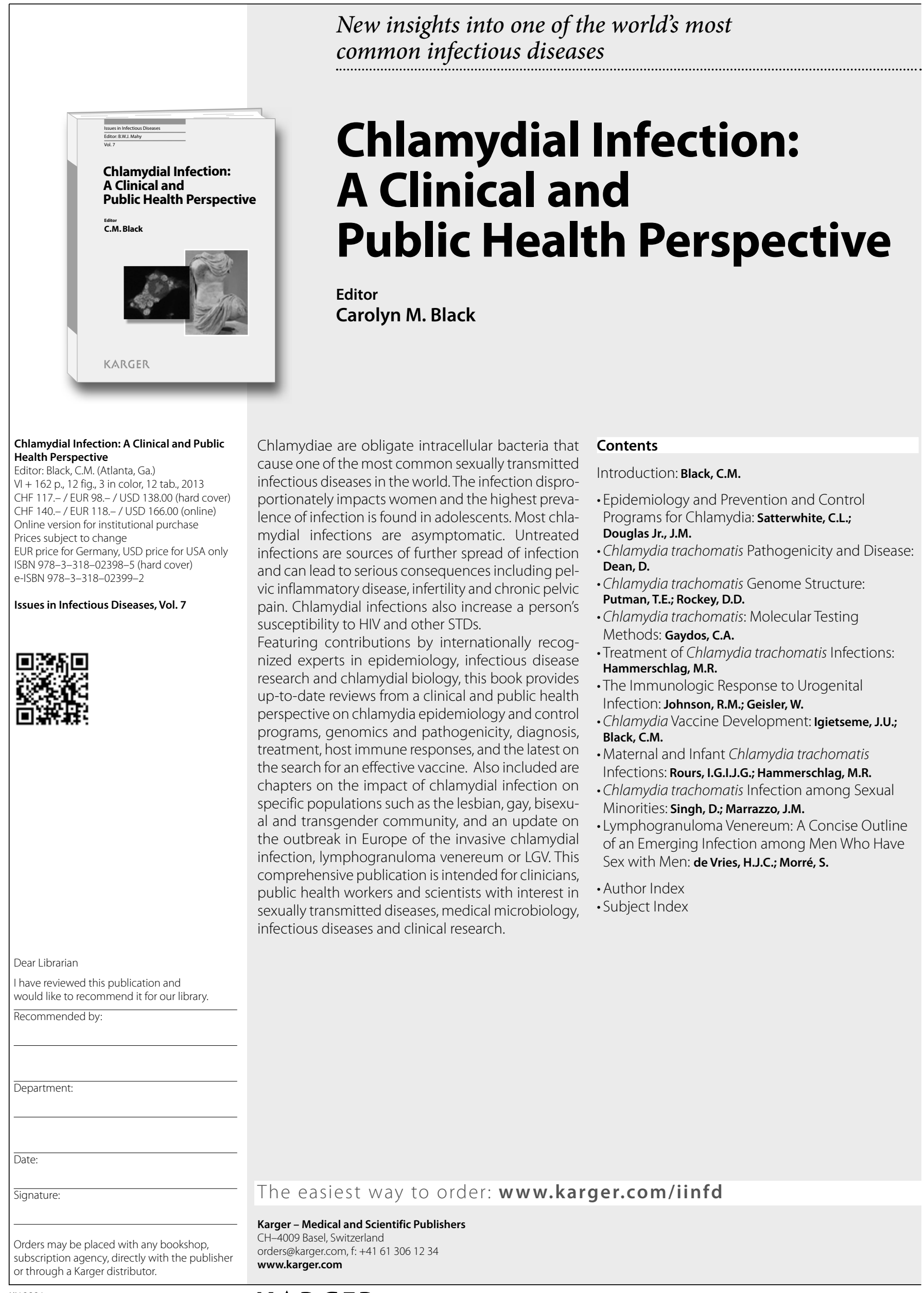




\section{Medical Principles
and Practice}

International Journal of the Kuwait University Health Sciences Centre

Founded and edited by Mustafa Khogali in 1989; continued by Basil Al-Nakib (1990-1993);

Naji S. Al-Zaid (1994-1998, and 2006); Farida Al-Awadi (1999-2005)

\section{Editorial Board (Kuwait)}

\section{Editor-in-Chief}

Azu Owunwanne

\section{Editor}

Ludmil Benov

\section{Members}

Adekunle Adekile

Nawaf Al-Mutairi

Naser Behbehani

Ajit Brindhaban

James D. Craik

Eino Honkala

Joseph Longenecker

Rajaa Marouf

Abu Salim Mustafa

Oludotun Phillips

\section{International Advisory Board}

James Aikens, Ann Arbor, Mich., USA

George J. Dohrmann, Chicago, Ill., USA

Ashok K. Grover, Hamilton, Ont., Canada

Seyed E. Hasnain, Hyderabad, India

Kewal K. Jain, Basel, Switzerland

Jasbir S. Juggi, Gurgaon, India

Anne M. Kuijpers-Jagtman, Nijmegen, The Netherlands

Simon Y.K. Law, Hong Kong, China

Edward Y. Lee, Boston, Mass., USA

Fiona Macdonald, Birmingham, UK

Daniel Markovich, St. Lucia, Qld., Australia

Vincent Marks, Haslemere, UK

Michael M. Meguid, Syracuse, N.Y., USA

Allie Moosa, Cape Town, South Africa

Ferid Murad, Houston, Tex., USA

Clive P. Page, London, UK

Fazlul H. Sarkar, Detroit, Mich., USA

Christian S. Stohler, Baltimore, Md., USA

Matti Uusitupa, Kuopio, Finland

Basil Varkey, Milwaukee, Wisc., USA

Franklin M.M. White, Victoria, B.C., Canada 


\section{Medical Principles and Practice}

\section{Mission Statement}

Medical Principles and Practice, the journal of the Kuwait University Health Sciences Centre, aims to be a publication of international repute that serves as a medium for dissemination and exchange of scientific knowledge in the health sciences.

\section{Objectives}

1. To publish original research in the health sciences.

2. To publish peer-reviewed articles of current international interest in the form of papers, solicited reviews, case reports, short communications, conference proceedings, discussion forums and letters.

\section{Submission}

Manuscripts, written in English (the preferred wordprocessing package is MS-Word), shall be submitted using the online submission website at:

\section{www.karger.com/mpp}

Should you experience any problems with your online submission, please contact the Editorial Office of Medical Principles and Practice:

\section{mpp@hsc.edu.kw}

Professor Azu Owunwanne

Editor-in-Chief, 'Medical Principles and Practice' 4th Floor, Faculty of Medicine

Health Sciences Centre

Kuwait University

PO Box 24923

Safat 13110

Kuwait

Tel. +96525340479 or +96524986680

Fax +965 25333094

www.hsc.edu.kw/vpo/mpp/

\section{Conditions}

All articles in this journal are Open Access and meet the requirements of funding bodies or academic institutions. Articles are licensed under the terms of the Creative Commons Attribution-NonCommercial 3.0 Unported license (CC BY-NC) (www.karger.com/ OA-license), applicable to the online version of the article only. For research funded by the Wellcome Trust, Research Councils UK (RCUK) and other organizations with the same requirements, papers are published under the Creative Commons Attribution 3.0 Unported license (CC BY 3.0) (www.karger.com/ OA-license-WT).

Please contact Karger's Open Access team at openaccess@karger.com with questions regarding your funding body

All manuscripts shall be accompanied by a cover letter from the corresponding author. Please note the Journal only corresponds with the designated author. Manuscripts are received with the explicit understanding that they are not under simultaneous consideration by any other journal and have not been previously published.

The corresponding author should disclose any conflict of interest associated with the study and must affirm that all co-investigators have been duly credited in the manuscript either as co-authors or in the acknowledgement section. To meet the criteria of authorship, it is necessary to have taken a significant part in the overall conception and design of the research or to have participated in the acquisition, analysis and interpretation of data as well as having written initial drafts of the manuscript, and revised and contributed to the final manuscript. Simply having been a part of the research group or contributing to data collection or providing patients or analysis of tests is not sufficient to satisfy the criteria for authorship.

Manuscripts must comply with the ethical standards recommended by the Helsinki Declaration. The editors realize that the use of anesthetics, analgesics and tranquilizers would defeat the purpose of some animal experiments. However, the use of painful or otherwise noxious stimuli must be carefully and thoroughly justified in the manuscript.

Like other international journals, Medical Principles and Practice regards plagiarism and self-plagiarism as unethical behaviour and potential authors are required to be vigilant in ensuring this does not occur in their manuscripts. For a useful discussion of this topic potential authors are referred to the publication by Bretag and Mahmud: Self-plagiarism or appropriate textual re-use. J Acad Ethics 2009;7:193205.

Submission of article(s) for consideration for publication requires transfer of copyright from the author to the publisher. All authors are required to sign the Assignment of Copyright agreement to consign the copyright of their paper to the publisher. Accepted manuscripts become the property of the Journal and may not be reproduced by any means, in whole or in part, without the written consent of the publisher. The copyright shall become void if the manuscript is not accepted for publication.

\section{Review Procedure}

All submitted manuscripts are reviewed by the editors for adequacy of documentation, composition and adherence to the guidelines of the Journal. Manuscripts not submitted in accordance with these guidelines will be returned to the author for correction before review. Manuscripts considered suitable for review are sent to at least two reviewers for evaluation. All reviews are confidential. The reviewers are asked to assess the originality, scientific merit, and design of the study, including statistical analysis, professional interest, and overall quality of the manuscript. The reviewer may recommend the manuscript be accepted as is, be revised or rejected. It is unusual for a manuscript to be accepted without revision. Deadline for submission of the revised manuscript is 3 months from the date the reviewers comments are sent to the corresponding author. The revised manuscript is then reviewed for compliance with reviewers' recommendations and, if deemed acceptable, is edited for clarity, accuracy and style.

\section{Arrangement}

Title page: The first page shall indicate the title, authors' names, institution where the work was conducted, exact postal address of the corresponding author complete with postal code and telephone and e-mail address, a short title for use as running head, and a list of 3-10 key words that reflect the content of the paper.

Abstract: Abstracts for Original Research Papers shall not exceed 250 words and should be structured to include four clearly identifiable areas of content: Objective: the rationale and importance of the study. Materials/Subjects and Methods: description of the materials, animals or subjects, basic design, procedures and the analytical techniques.

Results: major findings.

Conclusion: significant implication of the finding.

Abstracts for Case Reports shall not exceed 100 words and be structured as follows: Objective, Clinical Presentation and Intervention, and Conclusion. Text: Manuscripts shall be double spaced using Times New Roman 12-point font. The title page, abstract, and text of the manuscript shall each be submitted separately online. The text of the manuscript includes the list of references, which shall begin on a separate page, any tables, with each table beginning on a separate page, and the figure legend page. The manuscript shall be numbered sequentially starting with the title page. Major section headings are bold subheadings are italicized. Generic names shall be used. The use of acronyms is discouraged. Abbreviations shall be explained the first time they appear in the abstract and in the text. Scientific measurements shall be given in SI units. Any statistical procedure used shall be either described in detail or supported by references. The actual calculated $\mathrm{p}$ value shall be given

Original Research Papers: Laboratory or Clinical In vestigations are limited to approximately 16 pages, including references (maximum of 30), tables and figures. The text shall consist of Introduction, $\mathrm{Ma}$ terials and Methods (laboratory investigations) or Subjects and Methods (clinical investigations), Results, Discussion, Conclusion, References, Tables, Figure Legends and Figures.

Short Communications: These follow the structure of original papers but are limited to 5 manuscript pages (approximately 1,000 words) including a maximum of 10 references and 1 table or figure.

Case Reports: These consist of an Introduction, Clinical Presentation and Intervention, Discussion that includes the importance of the case reported and Conclusion. Case Reports shall be limited to 5 typewritten pages with a maximum of 10 references Reviews: These are solicited by the Journal on research of current interest and are limited to 35 pages including references, tables and figures.

Letters: Comments on previously published articles or issues of interest to the public. They should be brief, concise and to the point. Letters commenting on previously published articles shall be received within 1 year of publication of the said article. Al letters are subject to editing.

Acknowledgement: Please provide on a separate page if applicable.

\section{References}

In-text Citations: References shall be numbered consecutively in the text using Arabic numerals in [square brackets].

Reference List: The order of references in the list of references shall be in the order in which they are first mentioned in the text. Manuscripts accepted for publication but not yet published may be cited, but must be referred to as 'in press'. Provide the first 3 authors' names (followed by et al. if more authors). Write the last names of the authors followed

\section{KARGER}

E-Mail karger@karger.com www.karger.com 
by initials with no punctuation other than a comma to separate names. The final name or et al. shall be followed by a colon, then the title of the article with only the first word capitalized (lower case for remainder of title).The name of the journal, the year published, volume, and the complete range of pages must be listed. Abbreviate journal names according to the Index Medicus system. Also see International Committee of Medical Journal Editors: Uniform requirements for manuscripts submitted to biomedical journals (www.icmje.org).

Reference Management Software: Use of EndNote is recommended for easy management and formatting of citations and reference lists.

\section{Examples}

(a) Papers published in periodicals: Chatel J-M, Bernard $\mathrm{H}$, Orson FM: Isolation and characterization of two complete Ara h 2 isoforms cDNA. Int Arch Allergy Immunol 2003;131:14-18.

(b) Papers published only with DOI numbers: Theoharides TC, Boucher W, Spear K: Serum interleukin- 6 reflects disease severity and osteoporosis in mastocytosis patients. Int Arch Allergy Immunol DOI: $10.1159 / 000063858$.

(c) Monographs: Matthews DE, Farewell VT: Using and Understanding Medical Statistics, ed 3, revised. Basel, Karger, 1996.

(d) Edited books: DuBois RN: Cyclooxygenase-2 and colorectal cancer; in Dannenberg AJ, Dubois RN (eds): COX-2. Prog Exp Tum Res. Basel, Karger, 2003, vol 37, pp 124-137.

Tables and illustrations: Prepare each table or figure on a separate page and identify each using Arabic numerals. Tables require a heading; figures a legend, which shall be prepared on a separate page. Due to technical reasons, figures with a screen background will not be accepted. Electronically submitted b/w half-tone and color illustrations must have a final resolution of $300 \mathrm{dpi}$ after scaling, line drawings one of 800-1,200 dpi. Photomicrographs shall be calibrated on the print by adding a calibration bar (e.g. bar $=1 \mu \mathrm{m})$. Patients shown in photographs shall have their identity concealed or provide written consent for publication. If any tables or figures submitted have been published elsewhere, written consent for republication must be obtained by the author from the holders of the copyright (usually the authors and publishers)

\section{Color Illustrations}

Online edition: Color illustrations are reproduced free of charge. In the print version, the illustrations are reproduced in black and white. Please avoid referring to the colors in the text and figure legends. Print edition: Up to 6 color illustrations per page can be integrated within the text at CHF 800.00 per page.

\section{Digital Object Identifier (DOI)}

S. Karger Publishers supports DOIs as unique identifiers for articles. A DOI number will be printed on the title page of each article. DOIs can be useful in the future for identifying and citing articles published online without volume or issue information. More information can be found at www.doi.org

\section{Supplementary Materia}

Supplementary material is restricted to additional data that are not necessary for the scientific integrity and conclusions of the paper. Please note that all supplementary files will undergo editorial review and should be submitted together with the original manuscript. The Editors reserve the right to limit the scope and length of the supplementary material. Supplementary material must meet production quality standards for Web publication without the need for any modification or editing. In general, supplementary files should not exceed $10 \mathrm{Mb}$ in size. All figures and tables should have titles and legends and all files should be supplied separately and named clearly. Acceptable files and formats are: Word or PDF files, Excel spreadsheets (only if the data cannot be converted properly to a PDF file), and video files (.mov, .avi, .mpeg)

\section{NIH-Funded Research}

The US National Institutes of Health (NIH) mandates under the NIH Public Access Policy that final, peer-reviewed manuscripts appear in its digital database within 12 months of the official publication date. As a service to authors, Karger submits the final version of the article to the PubMed Central, where it will appear after a standard embargo. More details on NIH's Public Access Policy are available at http://publicaccess.nih.gov/policy.htm

\section{Self-Archiving}

Karger permits authors to archive their pre-prints (i.e. pre-refereeing) or post-prints (i.e. final draft post-refereeing) on their personal or institution's servers, provided the following conditions are met: articles may not be used for commercial purposes, they must be linked to the publisher's version, and acknowledge the publisher's copyright.

\section{Proofs}

Unless indicated otherwise, proofs are sent to the corresponding author and should be returned with the least possible delay. Alterations other than the correction of printer's errors are not accepted.

\section{Reprints}

Order forms and a price list are sent with the proofs. Orders submitted after the issue is printed are subject to considerably higher prices.
ISSN Print Edition: 1011-7571

ISSN Online Edition: 1423-0151

Journal Homepage: www.karger.com/mpp

Publication Data: 'Medical Principles and Practice'. Volume 23 with 6 issues appears in 2014.

Copyright: () 2014 S. Karger AG, Basel (Switzerland) All rights reserved. No part of this publication may be translated into other languages, reproduced or utilized in any form or by any means, electronic or mechanical, including photocopying, recording, microcopying, or by any information storage and retrieval system, without permission in writing from the publisher or, in the case of photocopying, direct payment of a specified fee to the Copyright Clearance Center.
Disclaimer: The statements, opinions and data contained in this publication are solely those of the individual authors and contributors and not of the publisher and the editor(s). The appearance of advertisements in the journal is not a warranty, endorsement, or approval of the products or services advertised or of their effectiveness, quality or safety. The publisher and the editor(s) disclaim responsibility for any injury to persons or property resulting from any ideas, methods, instructions or products referred to in the content or advertisements.

Bibliographic Indices: This journal is regularly listed in Index Medicus/MEDLINE, Science Citation Index, EMBASE/Excerpta Medica, IMEMR (WHO) and Reference Update.
Photocopying: This journal has been registered with the Copyright Clearance Center (CCC), as indicated by the code appearing on the first page of each article. For readers in the US, this code signals consent for copying of articles for personal or internal use, or for the personal or internal use of specific clients, provided that the stated fee is paid per copy directly to

Copyright Clearance Center Inc.

222 Rosewood Drive

Danvers, MA 01923 (USA)

A copy of the first page of the article must accompany payment. Consent does not extend to copying for general distribution, for promotion, for creating new works, or for resale. In these cases, specific written permission must be obtained from the copyright owner,

S. Karger AG, P.O. Box

CH-4009 Basel (Switzerland).

\section{KARGER}

E-Mail karger@karger.com www.karger.com 


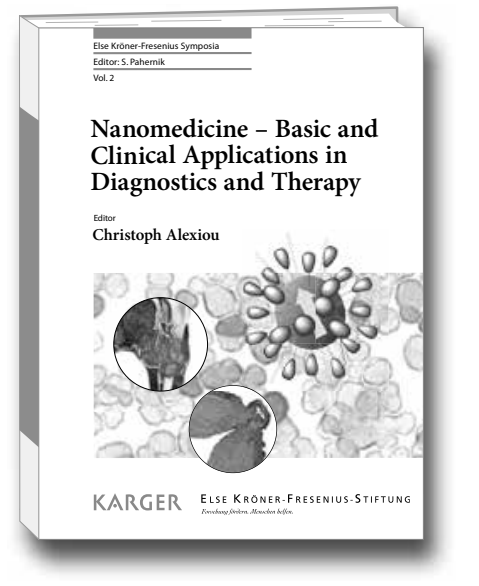

Nanomedicine - the application of nanotechnology to human health - is a promising field of research at the interface of physical, chemical, biological, and medical science. Recent advances have made it possible to analyze biological systems at cellular and subcellular levels, offering numerous promising approaches to improve medical diagnosis and therapy. It is expected that nanomedicine will have a great impact especially on drug delivery and imaging. In this context, the development of targeted, highly specific nanoparticles is of pivotal importance. The results of these advances will offer personalized diagnostic tools and treatments in the future.

Based on the 2nd Else Kröner-Fresenius-Symposium, this book presents a broad spectrum of topics ranging from nanoscale drug delivery/drug design to nanotoxicity and from diagnostics and imaging to therapeutic applications including antibody therapies. The contributions are authored by leading experts in the field and provide an excellent overview of the current knowledge in nanomedicine. Due to the interdisciplinary nature of the subject area this volume will be of special interest to physicians, biologists, chemists, engineers, and physicists as well as to students in the respective fields.

\section{Nanomedicine - Basic and Clinical Applications in Diagnostics and Therapy}

\author{
Editor \\ Christoph Alexiou
}

\section{Contents}

Preface: Pahernik, $\boldsymbol{s}$.

Introduction: Alexiou, C.

Speakers at the Symposium

Nanoscale Drug Delivery/Drug Design

Nanocarriers for the Delivery of Drugs, Genes, and Diagnostics: Torchilin, V.P.

Synthesis of Magnetic Nanoparticles and Magnetic Fluids for Biomedical Applications: Vékás, L.; Tombácz, E.; Turcu, R.; Morjan, I.; Avdeev, M.V.; Krasia-Christoforou, T.; Socoliuc, V. Nanotechnology-Based Spatiotemporal Controlled Drug Delivery Strategies: Biswas, S.; Kumar, C.S.S.R.

Nanotoxicity

Preclinical Efficacy and Toxicity Testing of Engineered Nanomaterials: Grossman, J.H.; McNeil, S.E.

Interactions of Carbon Nanotubes with the Immune System: Focus on Mechanisms of Internalization and Biodegradation: Fadeel, B.; Shvedova, A.A.; Kagan, V.E.

Diagnostics and Imaging

Magnetic Particle Imaging: Principles and Clinical Application: Buzug, T.M.; Sattel, T.F.; Erbe, M.; Biederer, S.; Finas, D.; Diedrich, K.; Vogt, F.; Barkhausen, J.; Borgert, J.; Lüdtke-Buzug, K.; Knopp, $T$.

www.karger.com/ekfsy
Nanoparticles in Clinical Trials: Hedgire, S.; McDermott, S.; Harisinghani, $M$.

Medical Applications of Plasmonic Nanoparticles: Alvarez-Puebla, R.A.; Liz-Marzán, L.M.

Pancreatic Cancer Stem Cells as New Targets for Diagnostics and Therapy: Clausell-Tormos, J.; Heeschen, $C$.

Therapeutic Applications

Nanomedicine Approaches for Cancer Stem Cell Targeting and Personalized Cancer Treatment: Block, I.; Schmidt, S.; Lund Hansen, P.; Riedel, A.; Christiansen, H.; Mollenhauer, J.

Targeted Iron Oxide Nanocomplex as a Theranostic Agent for Cancer: Chang, E.H. Local Cancer Therapy with Magnetic

Nanoparticles: Tietze, R.; Lyer, S.; Schreiber, E.; Mann, J.; Dürr, S.; Alexiou, C.

Parameters Influencing the Efficacy of Magnetic Heating of Small Breast Tumors: Hilger, I.; Kaiser, W.A.

Antibody Therapies

Galectins, Glycans, and Mucins as Targets for Novel and Specific Antibody Therapies in Gynecologic Cancer Therapies: Jeschke, U.; Wiest, I.R.M.; Schindlbeck, C.; Dian, D.; Friese, K. The Commercial Development of Antibodies as Drugs: Eaton, M.A.W.; Adair, J.R.

Author Index / Subject Index

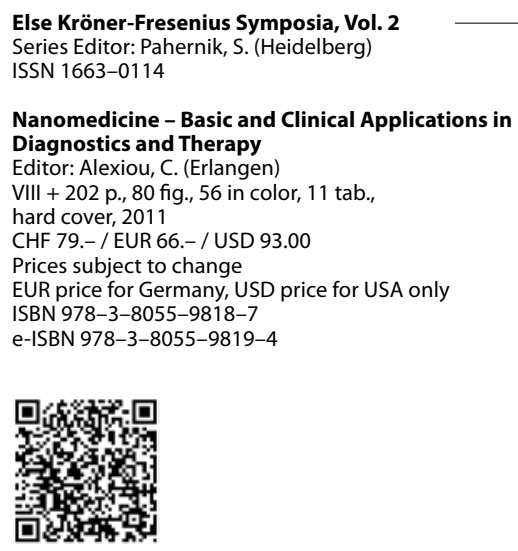

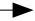
copy/ies

$\boldsymbol{\varepsilon}$ Postage and handling free with prepayment Payment:

Please charge to my credit card

- $\square$ American Express $\square$ Diners $\square$ Eurocard

$\square$ MasterCard

Card No.

-

¿ Exp. date:

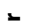

- CVV/CVC

(3 digits in the signature field on the back of Visa and MasterCard)

$\square$ Check enclosed $\quad \square$ Please bill me

Orders may be placed with any bookshop, subscription agency, directly with the publisher or through a Karger distributor.
Fax: +41 613061234

S. Karger AG, P.O. Box, CH-4009 Basel (Switzerland) E-Mail orders@karger.ch,www.karger.com

Name/Address: 


\section{Contents}

See the journal website for contents

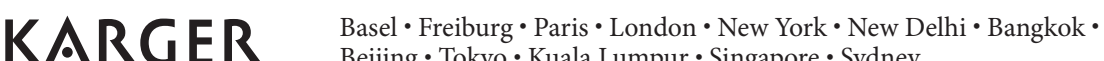
Beijing $\cdot$ Tokyo $\cdot$ Kuala Lumpur $\cdot$ Singapore $\cdot$ Sydney 


\section{Medical Principles and Practice}

Case Reports

275 Well-Leg Compartment Syndrome after Fracture Fixation in Hemilithotomy Position: Case Report of a Preventable Condition

Meena, S.; Trikha, V.; Saini, P.; Kumar, N.; KR, S. (New Delhi, India)

279 Moyamoya Syndrome as an Unusual Presenting Manifestation of Systemic Lupus Erythematosus in a Young Woman

Zhou, G.; An, Z. (Tianjin, China); Gokhale, S.

(Durham, N.C., USA)

282 Preliminary Results of Cord Blood Mononuclear Cell Therapy for Multiple System Atrophy: A Report of Three Cases

Wu, S.-H.; Yang, H.-X.; Jiang, G.-H.; Gong, D.-R.

(Liaocheng, PR China); Wang, L.-X.

(Wagga Wagga, N.S.W., Australia)
286 Bilateral Masseter and Internal Pterygoid Muscle Hypertrophy: A Diagnostic Challenge

Andreadis, D.; Stylianou, F.; Link-Tsatsouli, I.; Markopoulos, A. (Thessaloniki, Greece)

289 Acute Myocardial Infarction Caused by Tumor-Associated Thrombotic Thrombocytopenic Purpura: Case Report

Wang, J.; Cai, X.; Cheng, X.; Song, P.; Jiang, S.; Gong, J.

(Nanjing, China)

Letter to the Editor / Reply

292 Modifications to the PUFA Index: Are They Justified at This Stage?

Holmgren, C. (Paris, France); van Palenstein Helderman, W. (Linschoten, The Netherlands); Monse, B. (Manila, Philippines); Heinrich-Weltzien, R. (Jena, Germany); Benzian, H. (Milton Keynes, UK) 


\section{Medical Principles and Practice}

Review

195 Free Radicals: How Do We Stand Them? Anaerobic and Aerobic Free Radical (Chain) Reactions Involved in the Use of Fluorogenic Probes and in Biological Systems Liochev, S.I. (Durham, N.C., USA)

Original Papers

204 Evaluation of the Comparative Efficacy and Safety of Artemether-Lumefantrine, Artesunate-Amodiaquine and Artesunate-Amodiaquine-Chlorpheniramine (Artemoclo ${ }^{\mathrm{TM}}$ ) for the Treatment of Acute Uncomplicated Malaria in Nigerian Children

Falade, C.O.; Dada-Adegbola, H.O.; Ogunkunle, O.O. (Ibadan, Nigeria); Oguike, M.C. (London, UK); Nash, O.; Ademowo, O.G. (Ibadan, Nigeria)

212 Transthoracic Echocardiography and 6-Minute Walk Test in Kuwaiti Sickle Cell Disease Patients

Marouf, R.; Behbehani, N.; Zubaid, M.; Al Wazzan, H.; El Muzaini, H.; Abdulla, R.; Mojiminiyi, O.A.; Adekile, A.D. (Safat, Kuwait)

218 Orthognathic Surgery: Pretreatment Information and Patient Satisfaction

AlKharafi, L.; AlHajery, D.; Andersson, L. (Kuwait City, Kuwait)

225 Influence of Recurrent Electroconvulsive Therapy on Cardiac Function

Alpak, G.; Ercan, S.; Alici, H.; Bulbul, F. (Gaziantep, Turkey); Altunbas, G. (Kilis, Turkey); Alici, D.; Saricicek, V.; Davutoglu, V. (Gaziantep, Turkey)

229 Relationship between 25-Hydroxyvitamin D and Newly Diagnosed Type 2 Diabetes Mellitus in Postmenopausal Women with Osteoporosis

Vujosevic, S.; Borozan, S.; Radojevic, N.; Aligrudic, S.; Bozovic, D. (Podgorica, Montenegro)
234 The $\mathrm{CHA}_{2} \mathrm{DS}_{2}$-VASc Score as a Predictor of Left Atrial Thrombus in Patients with Non-Valvular Atrial Fibrillation Uz, O. (Istanbul, Turkey); Atalay, M. (Merzifon, Turkey); Doğan, M.; Isilak, Z.; Yalcin, M.; Uzun, M.; Kardesoglu, E.; Cebeci, B.S. (Istanbul, Turkey)

239 Switch-Associated Protein 70 Antibodies in Multiple Sclerosis: Possible Association with Disease Progression Türkoğlu, R.; Gencer, M.; Ekmekçi, D.; Ulusoy, C.; Erdağ, E.; Şehitoğlu, E.; Çavuş, F.; Haytural, H.; Küçükerden, M.; Yalçınkaya, N.; Turan, S.; Akbaş-Demir, D.; Çoban, A.; Vural, B.; Tüzün, E. (Istanbul, Turkey)

Oversights, Confusions and Misinterpretations Related to Self-Care and Medication in Diabetic and Renal Patients Mira, J.J. (Elche, Spain/Alicante, Spain/Alcorcón, Spain); Ortiz, L. (Elche, Spain); Lorenzo, S.; Royuela, C. (Alcorcón, Spain); Vitaller, J.; Pérez-Jover, V. (Elche, Spain)

253 The Thrombotic Events in Polycythemia Vera Patients May Be Related to Increased Oxidative Stress

Durmus, A.; Mentese, A.; Yilmaz, M.; Sumer, A. (Trabzon, Turkey) Akalin, I. (Istanbul, Turkey); Topal, C.; Alver, A. (Trabzon, Turkey)

259 Priapism in Homozygous Sickle Cell Patients: Important Clinical and Laboratory Associations

Madu, A.J.; Ubesie, A.; Ocheni, S.; Chinawa, J.; Madu, K.A.; Ibegbulam, O.G.; Nonyelu, C.; Eze, A. (Enugu, Nigeria)

264 Entangled Titanium Fibre Balls Combined with Nano Strontium Hydroxyapatite in Repairing Bone Defects Liu, P. (Shanghai, China/Hangzhou, China); Wang, N.; Hao, Y.; Zhao, Q.; Qiao, Y.; Li, H.; Li, J. (Shanghai, China)

271 Degrees of Kidney Disease in Nigerian Adults with Sickle-Cell Disease

Aneke, J.C. (Nnewi, Nigeria/Ile-Ife, Nigeria); Adegoke, A.O.; Oyekunle, A.A.; Osho, P.O.; Sanusi, A.A. (Ile-Ife, Nigeria); Okocha, E.C.; Ibeh, N.C. (Nnewi, Nigeria); Akinola, N.O.; Durosinmi, M.A. (Ile-Ife, Nigeria)

(Continued on inside back cover) 